\title{
A Series of COX-2 Inhibitors Endowed with NO-Releasing Properties: Synthesis, Biological Evaluation, and Docking Analysis
}

\author{
Sara Consalvi, ${ }^{*[\mathrm{a}]}$ Giovanna Poce, ${ }^{[\mathrm{a}]}$ Rino Ragno, ${ }^{[\mathrm{a}]}$ Manuela Sabatino ${ }^{[\mathrm{a}]}$ Concettina La Motta, ${ }^{[\mathrm{b}]}$ \\ Stefania Sartini, ${ }^{[b]}$ Vincenzo Calderone ${ }^{[b]}$ Alma Martelli, ${ }^{[b]}$ Carla Ghelardini, ${ }^{[c]}$ \\ Lorenzo Di Cesare Mannelli, ${ }^{[c]}$ and Mariangela Biava ${ }^{[a]}$
}

\begin{abstract}
Herein we report the synthesis, biological evaluation, and docking analysis of a class of cyclooxygenase-2 (COX-2) inhibitors with nitric oxide (NO)-releasing properties. In an earlier study, a number of selective COX-2 inhibitors/NO donors were developed by conjugating a diarylpyrrole scaffold endowed with selective COX-2 inhibitory properties with various nitrooxyalkyl side chains such as esters, $\alpha$-amino esters, amides, $\alpha$ amino amides, ethers, $\beta$-amino ethers, inverse esters, and amides. These candidates were found to have high in vitro po-
\end{abstract}

tencies (COX-2 inhibition at $10 \mu \mathrm{m}: \geq 96 \%$ ), great efficacy in determining NO-vasorelaxing responses, and good antinociceptive activity in an abdominal writhing test. Among the compounds synthesized in the present work, derivative $\mathbf{2} \mathbf{b}$ [2 (2-(1-(3-fluorophenyl)-2-methyl-5-(4-sulfamoylphenyl)-1 $\mathrm{H}$ pyrrol-3-yl)acetamido)ethyl nitrate] showed particularly outstanding activity, with efficacy similar to that of celecoxib even at very low concentrations.

\section{Introduction}

Conventional nonsteroidal anti-inflammatory drugs (NSAIDs) are widely used for treating different pathological conditions, from small injuries, headache or fever to chronic and severe pain. The efficacy of this class of drugs in relieving inflammation is related to their capability to inhibit cyclooxygenase (COX) enzymes, thus preventing the production of prostaglandins from arachidonic acid. While the therapeutic effects are primarily mediated by cyclooxygenase-2 (COX-2) inhibition, the inhibition of cyclooxygenase-1 (COX-1) is responsible for the side effects of NSAIDs, including renal and gastrointestinal (GI) toxicities. For this reason, a class of drugs that selectively inhibit the COX-2 isoform (coxibs) has been developed and marketed. ${ }^{[1,2]}$ However, the complete inhibition of COX-2 has led to a lack of a balance in the prostanoid production at cardiovascular (CV) level and as a consequence, the long-term administration of coxibs resulted in an increased incidence of throm-

[a] Dr. S. Consalvi, Dr. G. Poce, Dr. R. Ragno, M. Sabatino, Dr. M. Biava Dipartimento di Chimica e Tecnologie del Farmaco,

Sapienza Università di Roma, Piazzale A. Moro 5, 00185 Roma (Italy) E-mail:sara.consalvi@uniroma1.it

[b] Dr. C. La Motta, Dr. S. Sartini, Dr. V. Calderone, Dr. A. Martelli Dipartimento di Farmacia, Università di Pisa, via Bonanno Pisano 6, 56126 Pisa (Italy)

[c] Dr. C. Ghelardini, Dr. L. Di Cesare Mannelli Dipartimento di Neurologia Psicologia, Area del Farmaco e Salute del Bambino, Università degli Studi di Firenze, Viale G. Pieraccini 6, 50139 Firenze (Italy)

PECIAL This article is part of a Special Issue on the 23rd National Meeting on Medicinal Chemistry (NMMC 2015, Salerno, Italy). To view the complete issue, visit:

http://onlinelibrary.wiley.com/doi/10.1002/cmdc.v11.16/issuetoc. botic events and a greater CV hazard in many patients. ${ }^{[3-6]}$ Therefore, different strategies have been adopted to obtain safer anti-inflammatory agents, with limited gastrointestinal and cardiovascular toxicity. ${ }^{[7,8]} \mathrm{A}$ valuable option is to design multitarget-directed ligands, combining pharmacophoric elements that are able to simultaneously modulate different targets into the same scaffold, in order to either decrease side effects or enhance anti-inflammatory activity. ${ }^{[9]}$ Dual fatty acid amide hydrolase (FAAH)/COX inhibitors are a representative example of this class of drugs. ${ }^{[10]}$

Another interesting strategy to decrease side effects due to COX inhibition is to develop "molecular hybrids" conjugating the COX-inhibiting scaffold with a moiety able to counteract side effects, such as a nitric oxide (NO) releasing group. ${ }^{[11,12]}$ $\mathrm{NO}$ is a small endogenous gasotrasmitter produced by three isozymes (NOS, NO synthases) in many cells and plays a pivotal role in blood pressure regulation, cell proliferation, vascular homeostasis and vasorelaxant processes. ${ }^{[13,14]}$ Due to its small size and to its very high reactivity, it serves as a potent local modulator that rapidly diffuses through membranes to target cells and it is involved in cell-to-cell communication. ${ }^{[15]}$ In the CV system it acts as a physiological vasodilator and mediates smooth muscle relaxation by modulating the soluble guanylyl cyclase-cyclic guanosine monophosphate (sGC-cGMP) pathway. ${ }^{[16]}$ It also inhibits platelet aggregation and is likely to prevent both early and later steps of atherogenesis by decreasing leucocyte adhesion to the vascular wall. ${ }^{[17]}$ In addition, it can regulate gastric blood flow and contribute to gastric mucosal defense by modulating mucus and bicarbonate secretion. ${ }^{[18]}$ The first example of COX-inhibiting nitric oxide donors 
<smiles>COc1ccc2cc([C@@H](C)C(=O)OCCCCO[N+](=O)[O-])ccc2c1</smiles>

(CINODs) is naproxcinod (AZD3582, produced by NicOx), resulting from the conjugation of a NO-releasing moiety to a NSAID scaffold. ${ }^{[12]}$ Hereafter, given the key role of NO at CV level, this strategy was applied to COX-2-selective inhibitors, in order to obtain more potent anti-inflammatory agents with an abated GI toxicity and an acceptable CV safety profile. ${ }^{[19-23]}$

In this context, we developed a number of selective COX-2 inhibitors/nitric oxide donors by conjugating a diarylpyrrole scaffold endowed with selective COX-2 inhibition properties $^{[24-32]}$ with different nitrooxyalkyl side chains, such as esters, $\alpha$-amino esters, amides, $\alpha$-amino amides, ethers, $\beta$-amino ethers, inverse esters and amides. ${ }^{[33-37]}$ This medicinal chemistry program led to the identification of very promising candidates (Figure 1), with high in vitro potencies (COX-2 inhibition at $10 \mu \mathrm{M} \geq 96 \%$ ), a great efficacy in determining NO-vasorelaxing responses and a good antinociceptive activity in the abdominal writhing test $\left(46-77 \%\right.$ decrease in writhing at $\left.10 \mathrm{mg} \mathrm{kg}^{-1}\right)$.

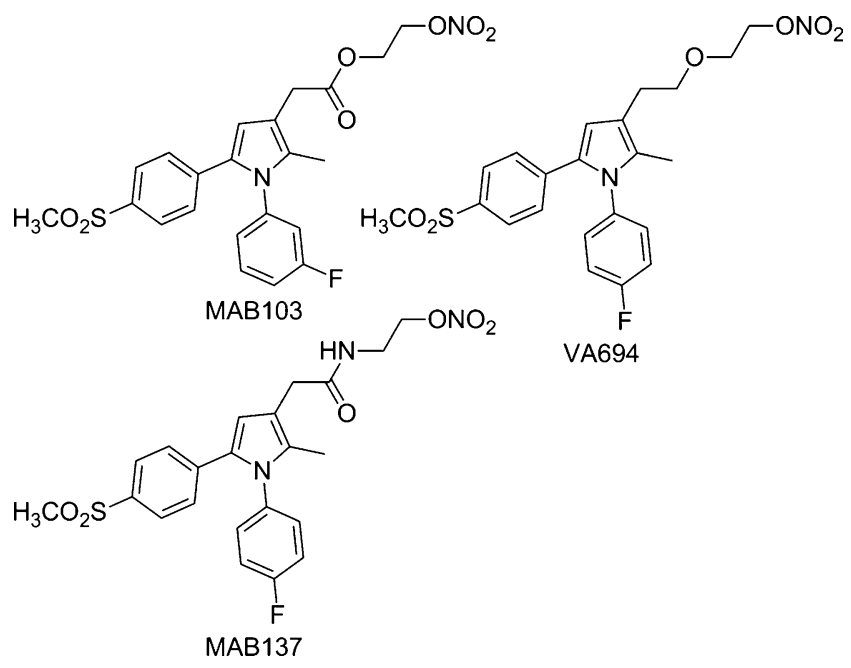

Figure 1. Structures of the most promising compounds previously synthesized.

To complete the picture, we present herein the development of a new class of sulfamoyl pyrroles as COX-2 inhibitors and NO donors. Indeed, assuming that the lower $\log P$ of arylsulfonamides could contribute to improved bioavailability and absorption with respect to arylsulfones, we explored the replacement of the methylsulfonyl moiety with a sulfamoyl one, to further improve in vivo activity. ${ }^{[1,38]}$ Thus, we prepared the nitrooxy acetic esters and amides 1-2 bearing a C5 sulfamoylphenyl group and a fluorinated N1 phenyl ring, according to structure-activity relationship (SAR) data emerged from the previously synthesized compounds. Finally, considering that such compounds undergo in vivo metabolism and that they could in turn be converted into the corresponding alcohols after NO release, the hydroxy derivatives 3-4 were synthesized and tested as probable metabolites (Figure 2).

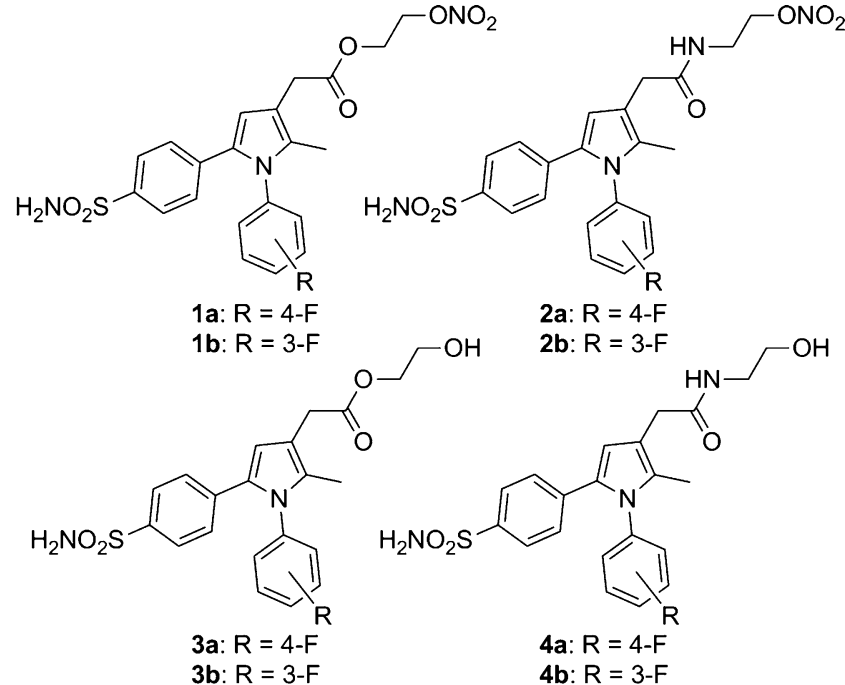

Figure 2. Structures of compounds 1-4.

\section{Results and Discussion}

\section{Chemistry}

Compounds 1-4 were prepared following the synthetic pathway described in Scheme 1. The acetic acid derivatives $\mathbf{5} \mathbf{a}, \mathbf{b}$ were synthesized as previously reported. ${ }^{[1]}$ Briefly, derivatives 1-3 were obtained through a coupling reaction between 2-hydroxyethyl nitrate, 2-aminoethyl nitrate or ethylene glycol and the suitable acid $\mathbf{5} \mathbf{a}, \mathbf{b}$ in the presence of 4 -dimethylaminopyridine (DMAP), $N^{\prime}$-(3-dimethylaminopropyl)- $N$-ethylcarbodiimide $(E D C I)$, and triethylamine (TEA). On the other hand, the hydroxy derivatives $4 \mathbf{a}$, $\mathbf{b}$ were obtained via an $\mathrm{EDCl} / 1$-hydroxybenzotriazole (HOBt) coupling stage.

\section{In vitro studies}

Inhibition of COX-1/COX-2 was assessed through an enzyme immunoassay and the prostanoids were quantified using the commercially available COX Inhibitor Screening Assay (Cayman Chemical Company, Ann Arbor, MI, USA). Data are reported as percent inhibition for all the tested compounds, and as $\mathrm{IC}_{50}$ values for the two most active ones ( $\mathbf{1} \mathbf{a}$ and $\mathbf{1} \mathbf{b}$, Table $\mathbf{1}$ ).

As reported in Table 1, nitrated acetic esters $1 \mathbf{a}, \mathbf{b}$ displayed the best activities against COX-2, with $I C_{50}$ values of $1.17 \pm 0.06$ and $0.41 \pm 0.01 \mu \mathrm{M}$, respectively. Such derivatives were found to be much more active than the corresponding hydroxy derivatives $3 \mathbf{a}, \mathbf{b}$, confirming the same trend observed for the methylsulfonyl analogues. ${ }^{[33]}$ On the other hand, the presence of the amide fragment was responsible for a drop in activity; in fact, both the acetic amides $\mathbf{2} \mathbf{a}$ and $\mathbf{2} \mathbf{b}$ proved to be less active than the corresponding acetic esters, proving that the combination of a nitroxyalkyl chain with an ester moiety guarantees the best interactions within the binding site. 


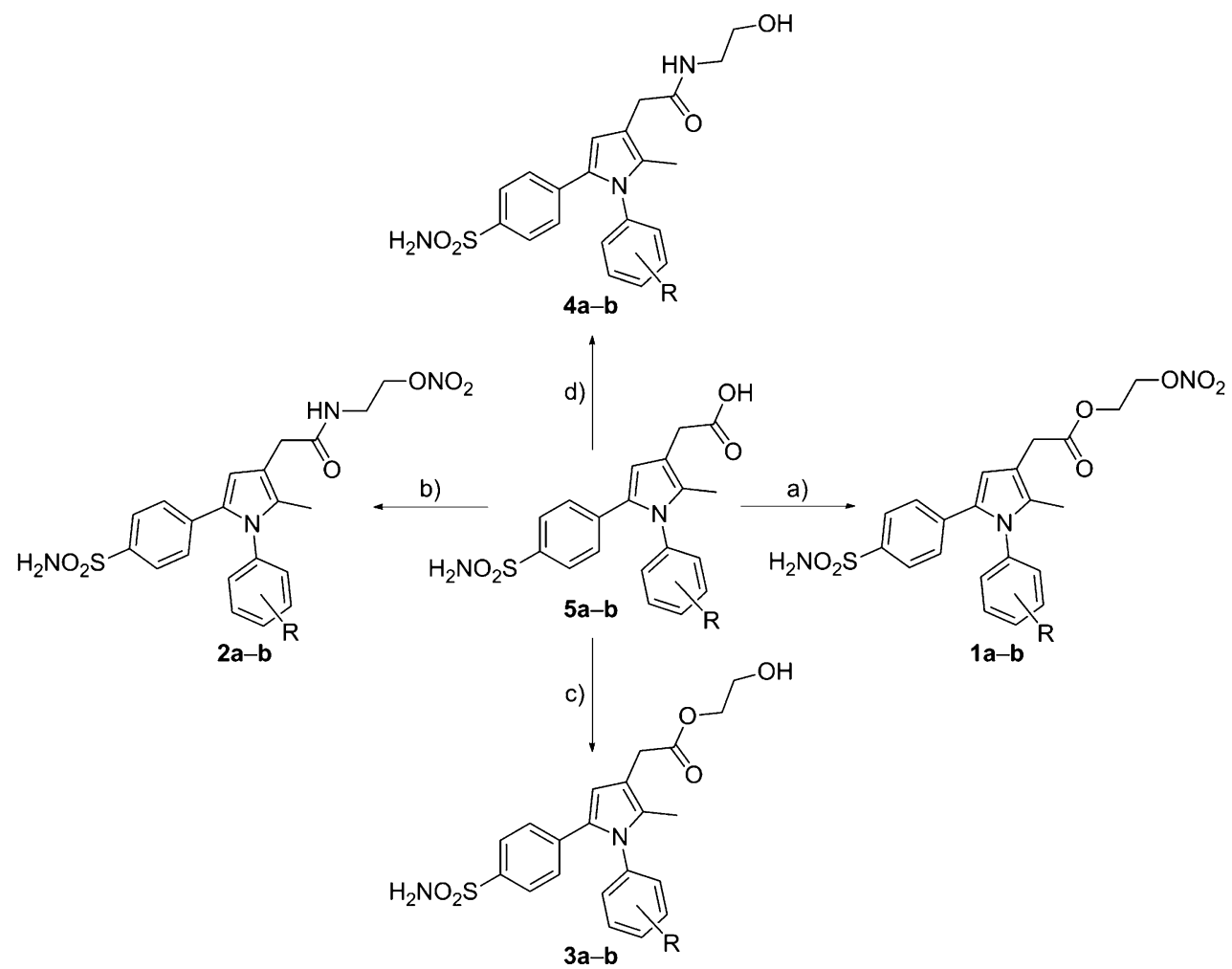

Scheme 1. Synthesis of compounds 1-4. Reagents and conditions: a) 2-nitrooxyethanol, DMAP, EDCl, TEA, $\mathrm{CH}_{2} \mathrm{Cl} \mathrm{L}_{2} / \mathrm{DMF}$ 10:1 (v/v), $15 \mathrm{~h}, \mathrm{RT}$; b) 2-nitrooxyethylamine, DMAP, EDCl, TEA, $\mathrm{CH}_{2} \mathrm{Cl}_{2} / \mathrm{DMF}$ 10:1 (v/v), $15 \mathrm{~h}, \mathrm{RT}$; c) ethylene glycol, DMAP, EDCl, TEA, $\mathrm{CH}_{2} \mathrm{Cl}_{2} / \mathrm{DMF} 10: 1$ ( $\left./ \mathrm{v} / \mathrm{v}\right), 15 \mathrm{~h}, \mathrm{RT}$; d) ethanolamine, $\mathrm{HOBt}$, EDCl, $\mathrm{CH}_{2} \mathrm{Cl}_{2} / \mathrm{DMF}$ 10:1 (v/v), $15 \mathrm{~h}, \mathrm{RT}$.

Table 1. In vitro activities of compounds $1-4$ and reference compound Dup-697 towards COX-1 and COX-2.

\begin{tabular}{|c|c|c|c|}
\hline \multirow[t]{2}{*}{ Compd } & \multicolumn{2}{|c|}{ Inhibition [\%] ${ }^{[\mathrm{a}]}$} & \multirow[t]{2}{*}{$\operatorname{COX}-2 \mathrm{IC}_{50}[\mu \mathrm{M}]^{[\mathrm{d}]}$} \\
\hline & COX-1 & $\operatorname{cox}-2$ & \\
\hline $1 \mathrm{a}$ & n.a..$^{[b]}$ & 86 & $1.17 \pm 0.06$ \\
\hline $1 \mathrm{~b}$ & n.a. ${ }^{[b]}$ & 89 & $0.41 \pm 0.01$ \\
\hline $2 \mathrm{a}$ & n.t. ${ }^{[c]}$ & 16 & n.d. ${ }^{[e]}$ \\
\hline $2 \mathrm{~b}$ & n.t. ${ }^{[c]}$ & 45 & n.d. ${ }^{[e]}$ \\
\hline $3 a$ & n.t. ${ }^{[c]}$ & 16 & n.d. ${ }^{[\mathrm{e}]}$ \\
\hline $3 b$ & n.t. ${ }^{[c]}$ & n.a. ${ }^{[b]}$ & n.d. ${ }^{[\mathrm{e}]}$ \\
\hline $4 a$ & n.t. ${ }^{[c]}$ & 18 & n.d. ${ }^{[\mathrm{e}]}$ \\
\hline $4 b$ & n.t. ${ }^{[c]}$ & 15 & n.d. ${ }^{[\mathrm{e}]}$ \\
\hline Dup-697 & - & 100 & - \\
\hline
\end{tabular}

[a] Each value is the mean of at least three determinations at a test compound concentration of $10 \mu \mathrm{M}$, carried out in triplicate; SEM $\leq 5 \%$. [b] Not active: no inhibition was observed at $10 \mu \mathrm{M}$. [c] Not tested. [d] Values are the mean \pm SD of at least three determinations, carried out in triplicate. [e] Not determined.

\section{Ex vivo NO releasing studies}

The capability of nitrooxy derivatives $\mathbf{1 - 2}$ in determining vasorelaxing responses was assessed using rat endothelium-denuded aortic rings pre-contracted with $\mathrm{KCl}(30 \mathrm{~mm})$ as an experimental model of vascular smooth muscle. Because NO induces vasodilator responses by activating GC and consequently increasing cGMP levels, the experiments were also performed in the presence of a GC inhibitor $(1 H-[1,2,4]$ oxadiazolo[4,3-a]qui- noxalin-1-one, ODQ), to confirm their mechanism of action. As reported in Table 2, all the tested compounds were effective in inducing vasorelaxing responses. In particular, the nitrooxy amides $\mathbf{2}$ a,b showed the best activity, with values of efficacy $\left(E_{\max }\right)$ and potency $\left(\mathrm{plC}_{50}\right)$ similar to those of naproxcinod, used as a control. Moreover, all the tested compounds were found to be inactive in the presence of $\mathrm{ODQ}$, proving that their efficacy was due to NO release. Notably, no vasorelaxing effect was observed at low concentrations, suggesting that these compounds gradually release NO (Figure 3); as a consequence, they are not responsible for a massive hypotensive effect in vivo, that is an essential feature for hybrid drugs.

Table 2. Nitric oxide releasing efficacy and potency for compounds 1-2 and naproxcinod, used as reference compound.

\begin{tabular}{|c|c|c|c|}
\hline Compound & $E_{\max }^{[a]}$ & $\mathrm{plC}_{50}^{[\mathrm{b}]}$ & $+\mathrm{ODQ}(1 \mu \mathrm{M})$ \\
\hline $1 \mathrm{a}$ & $47 \pm 0.5$ & n.c. ${ }^{[c]}$ & + \\
\hline $1 \mathrm{~b}$ & $59.1 \pm 0.4$ & $5.55 \pm 0.07$ & + \\
\hline $2 \mathrm{a}$ & $74.9 \pm 2.5$ & $5.82 \pm 0.04$ & + \\
\hline $2 b$ & $67.5 \pm 2.3$ & $5.49 \pm 0.00$ & + \\
\hline naproxcinod & $68.0 \pm 3.0$ & $6.33 \pm 0.06$ & + \\
\hline \multicolumn{4}{|c|}{$\begin{array}{l}\text { [a] Vasorelaxing efficacy was evaluated as the maximal vasorelaxing re- } \\
\text { sponse }\left(E_{\mathrm{max}}\right) \text {, expressed as a percentage of the contractile tone induced } \\
\text { by } \mathrm{KCl}(30 \mathrm{~mm}) \text {. [b] Potency is expressed as } \mathrm{plC}_{50} \text {, which was calculated } \\
\text { as the negative logarithm of the molar concentration of the tested com- } \\
\text { pounds required to evoke a half decrease in the contractile tone induced } \\
\text { by } \mathrm{KCl}(30 \mathrm{~mm}) .[\mathrm{c} \text { ] Not calculated. }\end{array}$} \\
\hline
\end{tabular}



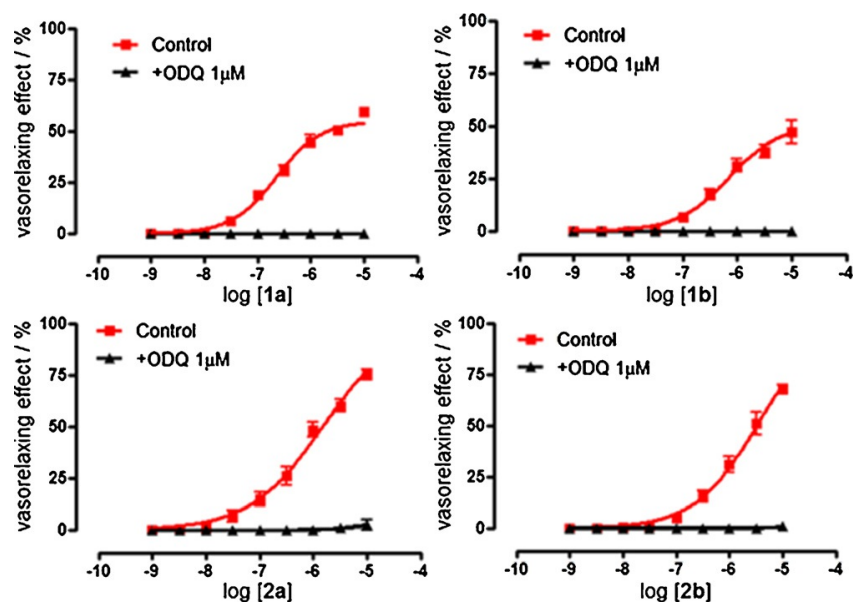

Figure 3. Concentration-response curve for the vasorelaxing effects exerted by compounds $\mathbf{1 - 2}$. The experiments were performed both in the presence and absence of ODQ $(1 \mu \mathrm{M})$. Data are the mean \pm SEM of $n=6$ experiments performed in sextuplicate.

In vivo studies: decrease in writhing in acetic acid induced abdominal constrictions in mice

Based on their in vitro potencies, compounds $\mathbf{1 - 2}$ and $\mathbf{4 b}$ were selected to assess their analgesic efficacy in a murine model of inflammatory pain. Such derivatives were orally administered 30 min before inducing writhing using an acetic acid intraperitoneal injection. Afterward, the number of writhes was measured and the results were expressed as a percentage of writhing decreased in comparison with the vehicle-treated mice (Table 3). All the tested compounds proved to be effec-

Table 3. Effects of $\mathbf{1 - 2}, \mathbf{4} \mathrm{b}$ and celecoxib in the mouse abdominal constriction test (acetic acid, $0.6 \%$ ).

\begin{tabular}{|c|c|c|c|c|}
\hline Treatment & \# Mice & $\begin{array}{c}\text { Dose } \\
{\left[\mathrm{mg} \mathrm{kg}^{-1} \text { p.o. }\right]^{[a]}}\end{array}$ & \# Writhes & $\begin{array}{c}\text { Writhes } \\
\text { decrease [\%] }\end{array}$ \\
\hline CMC & 28 & - & $33.6 \pm 2.2$ & - \\
\hline $1 \mathrm{a}$ & 5 & 10 & $27.6 \pm 3.5$ & 17.8 \\
\hline $1 \mathrm{a}$ & 6 & 30 & $19.0 \pm 2.9$ & 43.4 \\
\hline $1 \mathrm{~b}$ & 10 & 5 & $30.6 \pm 3.7$ & 8.9 \\
\hline $1 \mathrm{~b}$ & 10 & 10 & $18.9 \pm 3.0^{[b]}$ & 43.7 \\
\hline $1 \mathrm{~b}$ & 8 & 20 & $17.8 \pm 3.4^{[b]}$ & 47.0 \\
\hline $2 a$ & 10 & 5 & $26.7 \pm 3.3$ & 20.5 \\
\hline $2 a$ & 10 & 10 & $18.5 \pm 4.2^{[b]}$ & 44.9 \\
\hline $2 \mathrm{a}$ & 8 & 20 & $15.8 \pm 3.7^{[b]}$ & 53.0 \\
\hline $2 a$ & 9 & 40 & $16.7 \pm 2.5^{[b]}$ & 50.3 \\
\hline $2 b$ & 5 & 1 & $21.8 \pm 3.5^{[\mathrm{b}]}$ & 35.1 \\
\hline $2 b$ & 5 & 3 & $19.4 \pm 2.9^{[b]}$ & 42.3 \\
\hline $2 b$ & 6 & 10 & $16.7 \pm 3.5^{[\mathrm{b}]}$ & 50.3 \\
\hline $4 b$ & 7 & 3 & $26.4 \pm 2.5^{[c]}$ & 21.4 \\
\hline $4 b$ & 8 & 10 & $23.8 \pm 3.1$ & 29.2 \\
\hline $4 b$ & 6 & 30 & $21.2 \pm 2.7^{[b]}$ & 36.9 \\
\hline celecoxib & 10 & 1 & $19.3 \pm 2.5$ & 42.5 \\
\hline celecoxib & 10 & 5 & $16.6 \pm 2.2$ & 50.6 \\
\hline celecoxib & 10 & 10 & $14.2 \pm 2.3$ & 57.7 \\
\hline celecoxib & 10 & 20 & $13.9 \pm 2.7$ & 58.6 \\
\hline celecoxib & 10 & 40 & $10.2 \pm 2.1$ & 69.6 \\
\hline
\end{tabular}

[a] All drugs were administered per os $30 \mathrm{~min}$ before test. [b] $p<0.01$, [c] $p<0.05$ versus vehicle-treated mice. tive in reducing writhing. However, the nitrooxy amides $\mathbf{2} \mathbf{a}, \mathbf{b}$ exhibited a better pharmacological profile with respect to the acetic esters, differently from what emerged from the in vitro results. Indeed, the acetic esters $\mathbf{1} \mathbf{a}, \mathbf{b}$ were almost inactive at low doses, showing an appreciable efficacy only when administered at doses higher than $10 \mathrm{mg} \mathrm{kg}^{-1}$. Interestingly, acetic ester $\mathbf{1} \mathbf{b}$ was as active as the methylsulfonyl analogue MAB103 only in the $20 \mathrm{mg} \mathrm{kg}^{-1}$ range (MAB103 writhing inhibition at $\left.20 \mathrm{mg} \mathrm{kg}^{-1}: 47.5 \%\right)$, while it was even active at $10 \mathrm{mg} \mathrm{kg}^{-1}$ (MAB103 is inactive below $20 \mathrm{mg} \mathrm{kg}^{-1}$ ). ${ }^{[33]}$ On the other hand, the acetic amides showed good activities also in the 1$10 \mathrm{mg} \mathrm{kg}^{-1}$ range, probably because they are endowed with both a greater solubility and a higher stability, as previously demonstrated for the methylsulfonyl analogues. ${ }^{[37]}$ Therefore, their improved pharmacokinetic properties might counterbalance the lower affinity for the enzyme. Derivative $\mathbf{2} \mathbf{b}$ exhibited a unique profile: being the most active in the $3-10 \mathrm{mg} \mathrm{kg}^{-1}$ range, its efficacy was also evaluated at lower doses and it proved to be significantly effective even at $1 \mathrm{mg} \mathrm{kg}^{-1}$ (35\% decrease in writhing), with an efficacy similar to that of celecoxib and better than that of the methylsulfonyl analogue MAB137 (inactive below $3 \mathrm{mg} \mathrm{kg}^{-1}$ ). ${ }^{[3]}$ Finally, the hydroxy compound $4 \mathrm{~b}$ was found to be less active than the corresponding nitrooxyl analogue, confirming the trend observed for the previously synthesized compounds.

\section{Structure-based studies}

As previously reported, Vina was determined to be the most suitable docking program to study the binding mode of COX-2 inhibitors. ${ }^{[1]}$ Therefore, the newly synthesized compounds were all cross-docked by means of this program. In particular, compounds were modeled and cross-docked into all the available COX-2 experimental structures following the docking protocol previously reported. ${ }^{[31]}$ The lowest-energy poses were selected as the likely binding modes for the newly synthesized compounds. In general the new derivatives were found to dock into COX-2 similarly to the previously reported compounds. ${ }^{[31]}$ To avoid redundancy, the binding mode described here focuses on the most active compound in vivo $\mathbf{2} \mathbf{b}$ (see Table 3), which was found to inhibit COX-2 (see Table 1). The lowest energy docked pose of $\mathbf{2} \mathbf{b}$ was found in the celecoxib/ COX-2 experimental complex (PDB ID: 3LNI) displaying a binding mode highly superimposable to that of the reference compound (Figure 4). The three aromatic portions of the two compounds are highly overlapped and only small differences are visible for the 3-fluorophenyl group of $\mathbf{2} \mathbf{b}$ and the 4-methylphenyl group of celecoxib, i.e., the former is slightly rotated by $\sim 30$ degrees to allow accommodation of the 3-fluoro substituent. Differently from celecoxib, the $\mathbf{2} \mathbf{b}$ side chain fills a pocket formed mainly by hydrophobic residues (Met 113, Val 116, Leu 117, Val344, Ile 345, Val349, Leu 359, Ser 530, Leu 531 and Leu 534) and a moderate hydrogen bond distance is observable among the distal nitro group and the Ser 530 side chain hydroxy group (Ser $\left.513-\mathrm{NO}_{2} \cdots \mathrm{HO}_{\text {Ser513 }}=3.02 \AA\right)$. 


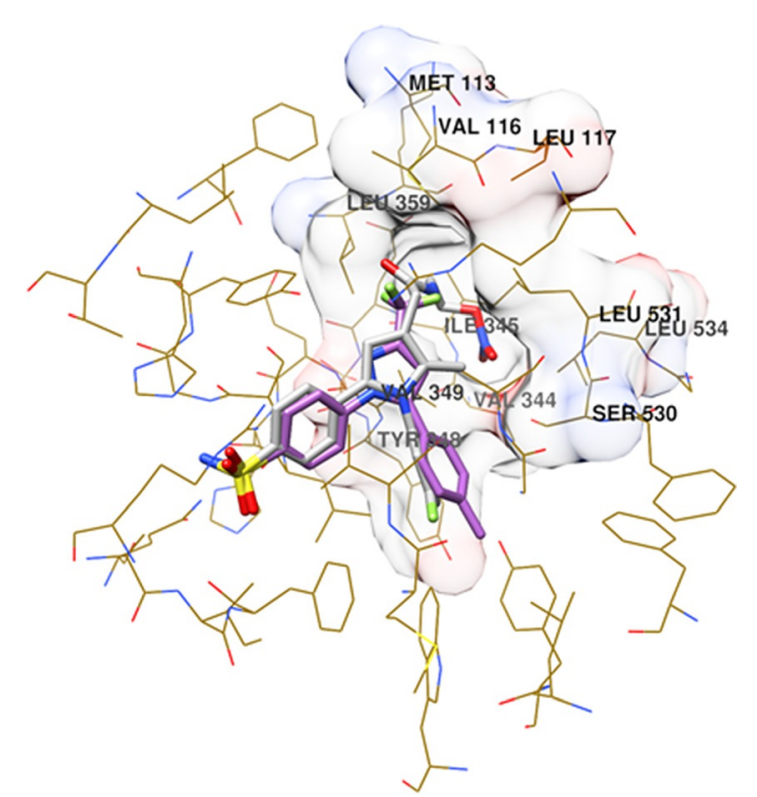

Figure 4. Docked proposed $\mathbf{2} \mathbf{b}$ (gray carbon atoms) binding mode into the binding site of PDB ID: 3LNI. For comparison, the co-crystallized celecoxib is also depicted (light magenta carbon atoms). The figure was generated using UCSF Chimera 1.10.2. The surface of Met 113, Val 116, Leu 117, Val 344, Ile 345, Val349, Leu 359, Ser 530, Leu 531 and Leu 534 residues is displayed to highlight the $\mathbf{2} \mathbf{b}$ side chain binding pocket.

\section{Conclusions}

We report the further structural modification of a series of pharmacodynamic hybrids based on a 1,5-diarylpyrrole scaffold. Some of the newly synthesized compounds were endowed with a good affinity for COX-2, proving that the replacement of methylsulfonylphenyl moiety at the $C 5$ of the pyrrole ring does not significantly affect the affinity for the target enzyme. The nitrooxyl derivatives 1-2 also exhibited good vasorelaxing properties, due to NO release. Overall, the tested compounds exhibited a good in vivo pharmacological profile and they all proved to be able to decrease writhing in a murine model of inflammatory pain. In particular, derivative $\mathbf{2} \mathbf{b}$ is characterized by an outstanding in vivo potency and proved to be effective even at $1 \mathrm{mg} \mathrm{kg}^{-1}$, showing a lower effective dose with respect to the most potent methylsulfonyl analogue previously synthesized (MAB137). Structure-based studies confirmed that it docks into COX-2 adopting a conformation highly superimposable to that of celecoxib, used as a reference compound. Being the most promising derivative of this class, further studies will address its pharmacokinetic profile and evaluate the contribution of the sulfamoyl moiety to its solubility and its bioavailability.

\section{Experimental Section}

\section{Chemistry}

All chemicals used were of reagent grade. Yields refer to purified products and are not optimized. Melting points were determined in open capillaries on a Gallenkamp apparatus and were uncorrect- ed. Sigma-Aldrich silica gel 60 (230-400 mesh) was used for column chromatography. Merck TLC plates (silica gel 60 F 254) were used for thin-layer chromatography (TLC). ${ }^{13} \mathrm{C}$ NMR and ${ }^{1} \mathrm{H}$ NMR spectra were recorded with a Bruker AC 400 spectrometer in the indicated solvent (TMS as the internal standard). The values of the chemical shifts are expressed in $\delta$. Mass spectra were recorded on an API-TOF Mariner by Perspective Biosystem (Stratford, TX, USA). Compound purity was assessed by elemental analysis obtained with a PE 2400 analyzer (PerkinElmer). The purity of target compounds was $>95 \%$.

General procedure for the preparation of nitrooxyalkyl and hydroxyalkyl esters $\mathbf{1} \mathbf{a}, \mathbf{b}$ and $3 \mathbf{a}, \mathbf{b}$ : To a solution of the appropriate acid $(5 \mathrm{a}, \mathbf{b})(0.200 \mathrm{~g}, 0.54 \mathrm{mmol})$ in a mixture of $\mathrm{CH}_{2} \mathrm{Cl}_{2} / \mathrm{N}, \mathrm{N}$-dimethylformamide (DMF) $(10: 1 \quad(v / v), 7 \mathrm{~mL})$, the suitable alcohol $(0.8 \mathrm{mmol}), \operatorname{DMAP}(0.109 \mathrm{~g}, 0.65 \mathrm{mmol}), \operatorname{EDCl}(0.106 \mathrm{~g}, 0.87 \mathrm{mmol})$ and TEA $(0.11 \mathrm{~mL}, 0.65 \mathrm{mmol})$ were added in sequence under a nitrogen atmosphere. The reaction was quenched after $15 \mathrm{~h}$ with water $(10 \mathrm{~mL})$ and extracted with $\mathrm{CH}_{2} \mathrm{Cl}_{2}(50 \mathrm{~mL} \times 3)$. The organic layer was washed with $1 \mathrm{~N} \mathrm{HCl}(50 \mathrm{~mL}), \mathrm{NaHCO}_{3}$ saturated solution $(50 \mathrm{~mL})$, brine $(50 \mathrm{~mL})$ and dried over $\mathrm{Na}_{2} \mathrm{SO}_{4}$. The organic phase was then filtrated and concentrated under reduced pressure to give a crude product that was purified on silica gel using a mixture of cyclohexane/ethyl acetate $(2: 1(\mathrm{v} / \mathrm{v}))$ as eluent to give derivatives $\mathbf{1} \mathbf{a}, \mathbf{b}$ and $\mathbf{3} \mathbf{a}, \mathbf{b}$ as pale-yellow and white powders, respectively.

2-(Nitrooxy)ethyl 2-(1-(4-fluorophenyl)-2-methyl-5-(4-sulfamoylphenyl)-1 H-pyrrol-3-yl)acetate (1 a): Pale-yellow powder, $(0.162 \mathrm{~g}$, $63 \%$ yield); mp: $109^{\circ} \mathrm{C}$; ${ }^{1} \mathrm{H}$ NMR $\left(400 \mathrm{MHz} \mathrm{CDCl}_{3}\right): \delta=2.05(\mathrm{~s}, 3 \mathrm{H}$, $\mathrm{CH}_{3}$ pyrrolic), 3.51 (s, $\left.2 \mathrm{H}, \mathrm{C}-\mathrm{CH}_{2}-\mathrm{CO}\right), 4.43(\mathrm{t}, J=3.18 \mathrm{~Hz}, 2 \mathrm{H}$, CO-O$\left.\mathrm{CH}_{2}-\mathrm{CH}_{2}-\mathrm{ONO}_{2}\right), 4.75\left(\mathrm{t}, J=3.18 \mathrm{~Hz}, 2 \mathrm{H}, \mathrm{CO}-\mathrm{O}-\mathrm{CH}_{2}-\mathrm{CH}_{2}-\mathrm{ONO}_{2}\right), 4.78$ (brs, $\left.2 \mathrm{H}, \mathrm{SO}_{2} \mathrm{NH}_{2}\right), 6.48(\mathrm{~s}, 1 \mathrm{H}, \mathrm{CH}$ pyrrolic), 7.17-7.28 $(\mathrm{m}, 6 \mathrm{H}, \mathrm{H}$ arom.), $7.68 \mathrm{ppm}\left(\mathrm{d}, J=7.34 \mathrm{~Hz}, 2 \mathrm{H}, \mathrm{H}\right.$ arom.); ${ }^{13} \mathrm{C}$ NMR $(100 \mathrm{MHz}$, $\left.\mathrm{CDCl}_{3}\right): \delta=169.5,158.8,146.6,143.4,142.5,134.9,127.8,126.4$, 123.1, 122.6, 121.8, 117.0, 114.4, 66.2, 62.3, 34.8, 10.3 ppm; IR (KBr): $\tilde{v}=3390,3300,1752,1630 \mathrm{~cm}^{-1}$; ESIMS: $\mathrm{m} / z 500.09[\mathrm{M}+\mathrm{Na}]^{+}$; HRMS-FAB $\mathrm{m} / \mathrm{z}[\mathrm{M}+\mathrm{H}]^{+}$calcd for $\mathrm{C}_{21} \mathrm{H}_{20} \mathrm{FN}_{3} \mathrm{O}_{7} \mathrm{~S}: 477.1006$, found: 477.1003; Anal. calcd for $\mathrm{C}_{21} \mathrm{H}_{20} \mathrm{FN}_{3} \mathrm{O}_{7} \mathrm{~S}$ : C 52.83, H 4.22, N 8.80, O 23.46, found: C 52.80, H 4.25, N 8.82, O 23.47 .

2-(Nitrooxy)ethyl 2-(1-(3-fluorophenyl)-2-methyl-5-(4-sulfamoylphenyl)-1 H-pyrrol-3-yl)acetate (1 b): Pale-yellow powder, $(0.149 \mathrm{~g}$, $58 \%$ yield); mp: $102^{\circ} \mathrm{C}$; ${ }^{1} \mathrm{H} \mathrm{NMR}\left(400 \mathrm{MHz} \mathrm{CDCl}_{3}\right): \delta=2.09(\mathrm{~s}, 3 \mathrm{H}$, $\mathrm{CH}_{3}$ pyrrolic), 3.55 (s, $\left.2 \mathrm{H}, \mathrm{C}-\mathrm{CH}_{2}-\mathrm{CO}\right), 4.43(\mathrm{t}, J=3.18 \mathrm{~Hz}, 2 \mathrm{H}, \mathrm{CO}-$ $\left.\mathrm{CH}_{2}-\mathrm{CH}_{2}-\mathrm{ONO}_{2}\right), 4.71\left(\mathrm{t}, J=3.18 \mathrm{~Hz}, 2 \mathrm{H}, \mathrm{CO}-\mathrm{CH}_{2}-\mathrm{CH}_{2}-\mathrm{ONO}_{2}\right), 4.75$ (brs, $\left.2 \mathrm{H}, \mathrm{SO}_{2} \mathrm{NH}_{2}\right), 6.48(\mathrm{~s}, 1 \mathrm{H}, \mathrm{CH}$ pyrrolic), $6.90(\mathrm{~d}, J=7.34 \mathrm{~Hz}, 1 \mathrm{H}$, $H$ arom.), $6.96(\mathrm{~d}, J=7.34 \mathrm{~Hz}, 1 \mathrm{H}, H$ arom.), $7.07-7.19(\mathrm{~m}, 3 \mathrm{H}, H$ arom.), 7.39-7.37 (m, $1 \mathrm{H}, H$ arom.), $7.68 \mathrm{ppm}(\mathrm{d}, J=7.34 \mathrm{~Hz}, 2 \mathrm{H}, H$ arom.); ${ }^{13} \mathrm{C}$ NMR $\left(100 \mathrm{MHz} \mathrm{CDCl}_{3}\right): \delta=169.5,163.8,144.6,143.4$, $142.5,134.9,131.2,127.5,127.0,126.4,122.6,117.0,114.4,111.1$, $106.5,69.2,62.3,34.8,10.3 \mathrm{ppm} ; \mathrm{IR}(\mathrm{KBr}): \tilde{v}=3366,3255,1749$, $1620 \mathrm{~cm}^{-1}$; ESIMS: $\mathrm{m} / \mathrm{z} 500.09[\mathrm{M}+\mathrm{Na}]^{+}$; HRMS-FAB $\mathrm{m} / \mathrm{z}[\mathrm{M}+\mathrm{H}]^{+}$ calcd for $\mathrm{C}_{21} \mathrm{H}_{20} \mathrm{FN}_{3} \mathrm{O}_{7} \mathrm{~S}$ : 477.1006, found: 477.1003; Anal. calcd for $\mathrm{C}_{21} \mathrm{H}_{20} \mathrm{FN}_{3} \mathrm{O}_{7} \mathrm{~S}$ : C 52.83, H 4.22, N 8.80, O 23.46 found: $\mathrm{C} \mathrm{52.80,} \mathrm{H}$ $4.25, \mathrm{~N} 8.78, \mathrm{O} 23.47$.

2-Hydroxyethyl 2-(1-(4-fluorophenyl)-2-methyl-5-(4-sulfamoylphenyl)-1H-pyrrol-3-yl)acetate (3a): White powder, $(0.107 \mathrm{~g}, 43 \%$ yield); $\mathrm{mp}: 131{ }^{\circ} \mathrm{C} ;{ }^{1} \mathrm{H} \mathrm{NMR}\left(400 \mathrm{MHz},\left[\mathrm{D}_{6}\right] \mathrm{DMSO}\right): \delta=1.98(\mathrm{~s}, 3 \mathrm{H}$, $\mathrm{CH}_{3}$ pyrrolic), 3.50 (s, 2 H, C-CH $\left.-\mathrm{CO}\right), 3.58$ (t, $J=3.20 \mathrm{~Hz}, 2 \mathrm{H}$, CO-O$\mathrm{CH}_{2}-\mathrm{CH}_{2}-\mathrm{OH}$ ), $4.05\left(\mathrm{t}, J=3.20 \mathrm{~Hz}, 2 \mathrm{H}, \mathrm{CO}-\mathrm{O}-\mathrm{CH}_{2}-\mathrm{CH}_{2}-\mathrm{OH}\right.$ ), 4.81 (brs, $1 \mathrm{H}, \mathrm{OH}), 6.46(\mathrm{~s}, 1 \mathrm{H}, \mathrm{CH}$ pyrrolic), $7.11(\mathrm{~d}, J=8.07 \mathrm{~Hz}, 2 \mathrm{H}, \mathrm{H}$ arom.) 7.22-7.27 (m, $6 \mathrm{H}, \mathrm{H}$ arom. and $\left.\mathrm{SO}_{2} \mathrm{NH}_{2}\right), 7.57 \mathrm{ppm}(\mathrm{d}, J=8.07 \mathrm{~Hz}$, $2 \mathrm{H}, \mathrm{H}$ arom.); ${ }^{13} \mathrm{C}$ NMR (100 MHz, [D $]$ ]DMSO): $\delta=169.5,158.8$, $146.6,143.4,142.5,134.9,127.8,126.4,123.1,122.6,121.8,117.0$, 
114.4, 66.2, 62.3, 34.8, 10.3 ppm; IR $(\mathrm{KBr}): \tilde{\nu}=3350, \quad 3256$, $1760 \mathrm{~cm}^{-1}$; ESIMS: $\mathrm{m} / \mathrm{z} 455.10[\mathrm{M}+\mathrm{Na}]^{+}$; HRMS-FAB $\mathrm{m} / \mathrm{z}[\mathrm{M}+\mathrm{H}]^{+}$ calcd for $\mathrm{C}_{21} \mathrm{H}_{21} \mathrm{FN}_{2} \mathrm{O}_{5} \mathrm{~S}$ : 432.1155, found: 432.1150; Anal. calcd for $\mathrm{C}_{21} \mathrm{H}_{21} \mathrm{FN}_{2} \mathrm{O}_{5} \mathrm{~S}$ : C 58.32, H 4.89, N, 6.48, O 18.50 found: C 58.35, H $4.91, \mathrm{~N}, 6.53, \mathrm{O} 18.45$.

2-Hydroxyethyl 2-(1-(3-fluorophenyl)-2-methyl-5-(4-sulfamoylphenyl)-1 H-pyrrol-3-yl)acetate (3 b): White powder, $(0.107 \mathrm{~g}, 46 \%$ yield); mp: $121{ }^{\circ} \mathrm{C} ;{ }^{1} \mathrm{H}$ NMR $\left(400 \mathrm{MHz},\left[\mathrm{D}_{6}\right] \mathrm{DMSO}\right): \delta=2.01(\mathrm{~s}, 3 \mathrm{H}$, $\mathrm{CH}_{3}$ pyrrolic), 3.50 (s, $\left.2 \mathrm{H}, \mathrm{C}-\mathrm{CH}_{2}-\mathrm{CO}\right), 3.58(\mathrm{t}, J=3.16 \mathrm{~Hz}, 2 \mathrm{H}, \mathrm{CO}-\mathrm{O}-$ $\mathrm{CH}_{2}-\mathrm{CH}_{2}-\mathrm{OH}$ ), $4.06\left(\mathrm{t}, J=3.16 \mathrm{~Hz}, 2 \mathrm{H}, \mathrm{CO}-\mathrm{O}-\mathrm{CH}_{2}-\mathrm{CH}_{2}-\mathrm{OH}\right.$ ), 4.81 (brs, $1 \mathrm{H}, \mathrm{OH}), 6.48(\mathrm{~s}, 1 \mathrm{H}, \mathrm{CH}$ pyrrolic), $7.01(\mathrm{~d}, J=7.37 \mathrm{~Hz}, 1 \mathrm{H}, \mathrm{H}$ arom.) $7.12(\mathrm{~d}, J=7.37 \mathrm{~Hz}, 2 \mathrm{H}, H$ arom.), $7.25-7.30(\mathrm{~m}, 4 \mathrm{H}, H$ arom. and $\left.\mathrm{SO}_{2} \mathrm{NH}_{2}\right), 7.41-7.45(\mathrm{~m}, 1 \mathrm{H}, \mathrm{H}$ arom.), $7.51 \mathrm{ppm}(\mathrm{d}, J=7.37 \mathrm{~Hz}, 2 \mathrm{H}$, $H$ arom.); ${ }^{13} \mathrm{C}$ NMR (100 MHz, $\left.\left[\mathrm{D}_{6}\right] \mathrm{DMSO}\right): \delta=169.5,158.8,146.6$, $143.4,142.5,134.9,131.7,127.8,126.4,123.1,121.8,117.0,114.4$, $11.8,108.5,66.2,62.3,34.8,10.3 \mathrm{ppm} ; \mathrm{IR}(\mathrm{KBr}): \tilde{v}=3383,3350$ $1765 \mathrm{~cm}^{-1}$; ESIMS: $\mathrm{m} / \mathrm{z} 455.10[\mathrm{M}+\mathrm{Na}]^{+}$; HRMS-FAB $\mathrm{m} / \mathrm{z}[\mathrm{M}+\mathrm{H}]^{+}$ calcd for $\mathrm{C}_{21} \mathrm{H}_{21} \mathrm{FN}_{2} \mathrm{O}_{5} \mathrm{~S}$ : 432.1155, found: 432.1159; Anal. calcd for $\mathrm{C}_{21} \mathrm{H}_{21} \mathrm{FN}_{2} \mathrm{O}_{5} \mathrm{~S}$ : C 58.32, H 4.14, N 6.48, O 18.76 found: $\mathrm{C} 58.35, \mathrm{H}$ $4.20, \mathrm{~N} 6.45, \mathrm{O} 18.73$.

General procedure for the preparation of nitrooxyalkyl amides 2 a,b: 2-aminoethylnitrate salt $(0.203 \mathrm{~g}, 1.2 \mathrm{mmol})$, DMAP $(0.164 \mathrm{~g}$, $0.97 \mathrm{mmol})$ and $\operatorname{EDCl}(0.159 \mathrm{~g}, 1.3 \mathrm{mmol})$ were added in sequence to a solution of the acid partner $(5 \mathrm{a}, \mathrm{b})(0.300 \mathrm{~g}, 0.81 \mathrm{mmol})$ dissolved in a mixture of $\mathrm{CH}_{2} \mathrm{Cl}_{2} / \mathrm{DMF} 10: 1(\mathrm{v} / \mathrm{v})(10 \mathrm{~mL})$, under a nitrogen flow. An excess of TEA $(0.17 \mathrm{~mL}, 1.3 \mathrm{mmol})$ was then added dropwise and the reaction was stirred at room temperature (RT) for $12 \mathrm{~h}$. The mixture was then quenched with water $(10 \mathrm{~mL})$ and extracted with $\mathrm{CH}_{2} \mathrm{Cl}_{2}(50 \mathrm{~mL} \times 3)$. The organic layer was washed with $1 \mathrm{~N} \mathrm{HCl}(50 \mathrm{~mL}), \mathrm{NaHCO}_{3}$ saturated solution $(50 \mathrm{~mL})$, brine $(50 \mathrm{~mL})$ and dried over $\mathrm{Na}_{2} \mathrm{SO}_{4}$. After filtration and concentration of the organic phase a crude material was obtained and was purified by chromatography on silica gel using as eluent a mixture of cyclohexane/ethyl acetate $(1: 1(v / v))$, affording compounds $2 \mathbf{a}, \mathbf{b}$ as pale-yellow powders.

\section{2-(2-(1-(4-Fluorophenyl)-2-methyl-5-(4-sulfamoylphenyl)-1 H-} pyrrol-3-yl)acetamido)ethyl nitrate (2a): Pale-yellow powder, (0.237 g, 50\% yield); mp: $127^{\circ} \mathrm{C} ;{ }^{1} \mathrm{H}$ NMR (400 MHz, [D $\mathrm{D}_{6}$ DMSO): $\delta=$ $1.97\left(\mathrm{~s}, 3 \mathrm{H}, \mathrm{CH}_{3}\right.$ pyrrolic), $3.26\left(\mathrm{~s}, 2 \mathrm{H}, \mathrm{C}-\mathrm{CH}_{2}-\mathrm{CO}\right) 3.37(\mathrm{t}, J=5.01 \mathrm{~Hz}$, $\left.2 \mathrm{H}, \mathrm{CO}-\mathrm{NH}-\mathrm{CH}_{2}-\mathrm{CH}_{2}-\mathrm{ONO}_{2}\right), 4.54\left(\mathrm{t}, J=5.01 \mathrm{~Hz}, 2 \mathrm{H}, \mathrm{CO}-\mathrm{NH}^{-} \mathrm{CH}_{2}-\right.$ $\left.\mathrm{CH}_{2}-\mathrm{ONO}_{2}\right), 6.43(\mathrm{~s}, 1 \mathrm{H}, \mathrm{CH}$ pyrrolic), $7.09(\mathrm{~d}, J=8.07 \mathrm{~Hz}, 2 \mathrm{H}, \mathrm{H}$ arom.), 7.21-7.29 (m, $6 \mathrm{H}$, arom. and $\left.\mathrm{SO}_{2} \mathrm{NH}_{2}\right), 7.56(\mathrm{~d}, J=8.07 \mathrm{~Hz}$, $2 \mathrm{H}, \mathrm{H}$ arom.), $8.11 \mathrm{ppm}$ (brs, $1 \mathrm{H}, \mathrm{CONH}) ;{ }^{13} \mathrm{CNMR}(100 \mathrm{MHz}$, [D $\mathrm{D}_{6}$ DMSO): $\delta=169.5,158.8,146.6,143.4,142.5,134.9,127.8,126.4$, 123.1, 122.6, 121.8, 117.0, 114.4, 72.5, 36.2, 34.8, 10.3 ppm; IR (KBr): $\tilde{v}=2967,2923,1735,1637 \mathrm{~cm}^{-1}$; ESIMS: $\mathrm{m} / z 499.11[\mathrm{M}+\mathrm{Na}]^{+}$; HRMS-FAB $\mathrm{m} / \mathrm{z}[\mathrm{M}+\mathrm{H}]^{+}$calcd for $\mathrm{C}_{21} \mathrm{H}_{21} \mathrm{FN}_{4} \mathrm{O}_{6} \mathrm{~S}: 477.1166$, found: 477.1158; Anal. calcd for: $\mathrm{C}_{21} \mathrm{H}_{21} \mathrm{FN}_{4} \mathrm{O}_{6} \mathrm{~S}: \mathrm{C} 52.94, \mathrm{H} 4.44, \mathrm{~N} 11.76$, O 20.15, found: C 53.00, H 4.43, N 11.70, O 20.13.

\section{2-(2-(1-(3-Fluorophenyl)-2-methyl-5-(4-sulfamoylphenyl)-1H-} pyrrol-3-yl)acetamido)ethyl nitrate (2 b): Pale-yellow powder, (0.242 g, $51 \%$ yield); mp: $125^{\circ} \mathrm{C} ;{ }^{1} \mathrm{H}$ NMR (400 MHz, [D $]$ ]DMSO): $\delta=$ $2.03\left(\mathrm{~s}, 3 \mathrm{H}, \mathrm{CH}_{3}\right.$ pyrrolic), $3.28\left(\mathrm{~s}, 2 \mathrm{H}, \mathrm{C}-\mathrm{CH}_{2}-\mathrm{CO}\right), 3.43(\mathrm{t}, J=5.14 \mathrm{~Hz}$, $\left.2 \mathrm{H}, \mathrm{CO}-\mathrm{NH}_{-} \mathrm{CH}_{2}-\mathrm{CH}_{2}-\mathrm{ONO}_{2}\right), 4.57\left(\mathrm{t}, J=5.14 \mathrm{~Hz}, 2 \mathrm{H}, \mathrm{CO}-\mathrm{NH}^{-\mathrm{CH}_{2}-}\right.$ $\left.\mathrm{CH}_{2}-\mathrm{ONO}_{2}\right), 6.46(\mathrm{~s}, 1 \mathrm{H}, \mathrm{CH}$ pyrrolic) $7.02(\mathrm{~d}, J=8.31 \mathrm{~Hz}, 1 \mathrm{H}, \mathrm{H}$ arom.), 7.13 (d, $J=8.31 \mathrm{~Hz}, 2 \mathrm{H}, H$ arom.), 7.18-7.33 (m, $4 \mathrm{H}, H$ arom. and $\left.\mathrm{SO}_{2} \mathrm{NH}_{2}\right), 7.51-7.57(\mathrm{~m}, 1 \mathrm{H}, \mathrm{H}$ arom.), $7.61(\mathrm{~d}, J=8.31 \mathrm{~Hz}, 2 \mathrm{H}, \mathrm{H}$ arom.), $8.15 \mathrm{ppm}$ (brs, $1 \mathrm{H}, \mathrm{CONH}) ;{ }^{13} \mathrm{C}$ NMR $\left(100 \mathrm{MHz},\left[\mathrm{D}_{6}\right] \mathrm{DMSO}\right)$ : $\delta=169.5,158.8,146.6,143.4,142.5,134.9,131.6,127.8,126.3$, 125.2, 121.4, 117.0, 114.4, 109.4, 11.9, 76.2, 37.3, 34.8, 10.3 ppm. IR (KBr): $\tilde{v}=3182,3079,1731,1635 \mathrm{~cm}^{-1}$; ESIMS: $\mathrm{m} / \mathrm{z} 499.11$
$[M+\mathrm{Na}]^{+}$; HRMS-FAB $\mathrm{m} / \mathrm{z}[\mathrm{M}+\mathrm{H}]^{+}$calcd for: 477.1166, found: 477.1158; Anal. calcd for: $\mathrm{C}_{21} \mathrm{H}_{21} \mathrm{FN}_{4} \mathrm{O}_{6} \mathrm{~S}$ : C 52.94, H 4.44, N 11.76, O 20.15, found: C 53.00, H 4.43, N 11.83, O 20.13 .

General procedure for the preparation of hydroxyalkyl amides $4 \mathrm{a}$,b: Ethanolamine $(0.067 \mathrm{~g}, 1.1 \mathrm{mmol}), \mathrm{HOBt}(0.168 \mathrm{~g}, 1.1 \mathrm{mmol})$, and $\mathrm{EDCl}(0.159 \mathrm{~g}, 1.3 \mathrm{mmol})$ were added in sequence to a solution of the suitable 1,5-diarylpyrrole-3-acetic acid $(5 \mathbf{a}, \mathbf{b}) \quad(0.300 \mathrm{~g}$, $0.8 \mathrm{mmol})$ in a mixture of $\mathrm{CH}_{2} \mathrm{Cl}_{2} / \mathrm{DMF}(10: 1(\mathrm{v} / \mathrm{v}), 10 \mathrm{~mL})$, under a nitrogen atmosphere. An excess of TEA $(0.17 \mathrm{~mL}, 1.3 \mathrm{mmol})$ was then added dropwise and the reaction was stirred at RT. After $12 \mathrm{~h}$, the mixture was quenched with water $(10 \mathrm{~mL})$ and extracted with $\mathrm{CH}_{2} \mathrm{Cl}_{2}(50 \mathrm{~mL} \times 3)$. The organic layer was washed with $1 \mathrm{~N} \mathrm{HCl}$ $(50 \mathrm{~mL}), \mathrm{NaHCO}_{3}$ saturated solution $(50 \mathrm{~mL})$, brine $(50 \mathrm{~mL})$ and dried over $\mathrm{Na}_{2} \mathrm{SO}_{4}$. After filtration and concentration of the organic phase the so obtained crude material was purified by chromatography on silica gel using ethyl acetate as eluent to give the desired products as white powders.

2-(1-(4-Fluorophenyl)-2-methyl-5-(3-sulfamoylphenyl)-1 H-pyrrol3-yl)- $\mathrm{N}$-(2-hydroxyethyl)acetamide (4a): White powder, $(0.271 \mathrm{~g}$, $71 \%$ yield); $\mathrm{mp}: 155^{\circ} \mathrm{C} ;{ }^{1} \mathrm{H}$ NMR $\left(400 \mathrm{MHz},\left[\mathrm{D}_{6}\right] \mathrm{DMSO}\right): \delta=2.06(\mathrm{~s}$, $3 \mathrm{H}, \mathrm{CH}_{3}$ pyrrolic), 3.12 (t, $J=5.14 \mathrm{~Hz}, 2 \mathrm{H}, \mathrm{CO}-\mathrm{NH}_{-} \mathrm{CH}_{2}-\mathrm{CH}_{2}-\mathrm{OH}$ ), 3.25 (s, $\left.2 \mathrm{H}, \mathrm{C}-\mathrm{CH}_{2}-\mathrm{CO}\right), 3.41\left(\mathrm{t}, J=5.14 \mathrm{~Hz}, 2 \mathrm{H}, \mathrm{CO}-\mathrm{NH}-\mathrm{CH}_{2}-\mathrm{CH}_{2}-\mathrm{OH}\right), 4.68$ (brs, $1 \mathrm{H}, \mathrm{OH}), 6.46(\mathrm{~s}, 1 \mathrm{H}, \mathrm{CH}$ pyrrolic), $7.11(\mathrm{~d}, J=7.89 \mathrm{~Hz}, 2 \mathrm{H}, \mathrm{H}$ arom.), $7.23-7.31\left(\mathrm{~m}, 6 \mathrm{H}, \mathrm{H}\right.$ arom. and $\left.\mathrm{SO}_{2} \mathrm{NH}_{2}\right), 7.57(\mathrm{~d}, J=7.89 \mathrm{~Hz}$, $2 \mathrm{H}, \mathrm{H}$ arom.), $7.83 \mathrm{ppm}$ (brs, $1 \mathrm{H}, \mathrm{CONH}) ;{ }^{13} \mathrm{C} \mathrm{NMR}(100 \mathrm{MHz}$, $\left.\left[\mathrm{D}_{6}\right] \mathrm{DMSO}\right): \delta: 171.9,160.2,147.0,144.0,142.9,134.6,128.0,127.3$, $126.2,121.9,121.5,116.0,113.7,66.9,41.8,33.9,10.1$ ppm; IR (KBr): $\tilde{v}=3358,3342,1752 \mathrm{~cm}^{-1}$; ESIMS: $\mathrm{m} / z$ 454.12 $[\mathrm{M}+\mathrm{Na}]^{+}$; HRMS-FAB $\mathrm{m} / \mathrm{z}[\mathrm{M}+\mathrm{H}]^{+}$calcd for $\mathrm{C}_{21} \mathrm{H}_{22} \mathrm{FN}_{3} \mathrm{O}_{4} \mathrm{~S}: 431.1315$, found: 431.1318; Anal. calcd for $\mathrm{C}_{21} \mathrm{H}_{22} \mathrm{FN}_{3} \mathrm{O}_{4} \mathrm{~S}$ : C 58.46, H 5.14, N 9.74, O 14.83 found: C 58.40, H 5.20, N 9.67, O 14.80.

2-(1-(3-Fluorophenyl)-2-methyl-5-(3-sulfamoylphenyl)-1 H-pyrrol3-yl)- $\mathrm{N}$-(2-hydroxyethyl)acetamide (4 b): White powder, $(0.256 \mathrm{~g}$, $67 \%$ yield); mp: $175^{\circ} \mathrm{C} ;{ }^{1} \mathrm{H}$ NMR ( $\left.400 \mathrm{MHz},\left[\mathrm{D}_{6}\right] \mathrm{DMSO}\right): \delta=2.04(\mathrm{~s}$, $3 \mathrm{H}, \mathrm{CH}_{3}$ pyrrolic), 3.15 (t, $\left.J=5.62 \mathrm{~Hz}, 2 \mathrm{H}, \mathrm{CO}-\mathrm{NH}_{-} \mathrm{CH}_{2}-\mathrm{CH}_{2}-\mathrm{OH}\right), 3.27$ (s, $\left.2 \mathrm{H}, \mathrm{C}-\mathrm{CH}_{2}-\mathrm{CO}\right), 3.46\left(\mathrm{t}, J=5.62 \mathrm{~Hz}, 2 \mathrm{H}, \mathrm{CO}-\mathrm{NH}_{-} \mathrm{CH}_{2}-\mathrm{CH}_{2}-\mathrm{OH}\right), 4.69$ (brs, $1 \mathrm{H}, \mathrm{OH}), 6.48(\mathrm{~s}, 1 \mathrm{H}, \mathrm{CH}$ pyrrolic), $7.04(\mathrm{~d}, J=7.82 \mathrm{~Hz}, 1 \mathrm{H}, \mathrm{H}$ arom.) $7.13(\mathrm{~d}, J=8.07 \mathrm{~Hz}, 2 \mathrm{H}, \mathrm{H}$ arom.), $7.19-7.33(\mathrm{~m}, 4 \mathrm{H}, \mathrm{H}$ arom. and $\left.\mathrm{SO}_{2} \mathrm{NH}_{2}\right), 7.49-7.51(\mathrm{~m}, 1 \mathrm{H}, H$ arom.), $7.60(\mathrm{~d}, J=8.07 \mathrm{~Hz}, 2 \mathrm{H}, H$ arom.), $7.90 \mathrm{ppm}$ (brs, $1 \mathrm{H}, \mathrm{CONH}) ;{ }^{13} \mathrm{C}$ NMR (100 MHz, [D 6 ]DMSO): $\delta=171.3,162.9,142.5,142.0,141.6,133.6,129.2,127.8,126.5$, 125.0, 120.9, 116.8, 112.6, 111.9, 106.8, 60.9, 40.8, 33.2, 9.6 ppm; IR $(\mathrm{KBr}): \tilde{v}=3346,3300,1750 \mathrm{~cm}^{-1}$; ESIMS: $\mathrm{m} / z \quad 454.12[\mathrm{M}+\mathrm{Na}]^{+}$; HRMS-FAB $\mathrm{m} / \mathrm{z}[\mathrm{M}+\mathrm{H}]^{+}$calcd for $\mathrm{C}_{21} \mathrm{H}_{22} \mathrm{FN}_{3} \mathrm{O}_{4} \mathrm{~S}: 431.1315$, found: 431.1309; Anal. calcd for $\mathrm{C}_{21} \mathrm{H}_{22} \mathrm{FN}_{3} \mathrm{O}_{4} \mathrm{~S}$ : C 58.46, H 5.14, N 9.74, O 14.83 found: C 58.90, H 5.17, N 9.77, O 14.86 .

\section{Biological assays}

In vitro anti-inflammatory studies: The inhibitory activity of compounds 1-4 against both COX-1 and COX-2 was determined by the commercially available COX Inhibitor Screening Assay (Cayman Chemical, Ann Arbor, MI, USA, cat. no. 560131), which exploits an enzyme immunoassay to measure $\mathrm{PGE}_{2 \alpha}$ produced by stannous chloride reduction of $\mathrm{PGEH}_{2}$, derived in turn by reaction between the target enzyme and the substrate, arachidonic acid. According to the manufacturer's protocol, test compounds $(10 \mu \mathrm{L})$ were incubated for $10 \mathrm{~min}$ at $37^{\circ} \mathrm{C}$ with assay buffer $(0.1 \mathrm{M}$ Tris- $\mathrm{HCl}, \mathrm{pH} 8$, $160 \mu \mathrm{L})$, Heme $(10 \mu \mathrm{L})$, and either ovine COX-1 or human recombinant COX-2 enzyme solution $(10 \mu \mathrm{M})$. Arachidonic acid $(10 \mu \mathrm{L})$ was then added, and the resulting mixture was incubated for $2 \mathrm{~min}$ at $37^{\circ} \mathrm{C}$. Enzyme catalysis was stopped by adding $\mathrm{HCl}(1 \mathrm{M}, 10 \mathrm{~mL})$ 
and the obtained $\mathrm{PGEH}_{2}$ was converted into $\mathrm{PGE}_{2 \alpha}$ with saturated stannous chloride solution $(20 \mu \mathrm{L})$. Prostanoids were finally quantified by enzyme immunoassay (EIA), and their amount was determined through interpolation from a standard curve. The percent inhibition of target enzyme by test compounds was calculated by comparing $\mathrm{PGE}_{2 \alpha}$ produced in compound-treated samples with that of the compound-free, control sample. The highly selective COX-2 inhibitor Dup-697 was used as the reference compound. All the test compounds were dissolved into dilute assay buffer, and their solubility was facilitated by using DMSO, whose concentration never exceeded $1 \%$ in the final reaction mixture. The inhibitory effect of test compounds was routinely estimated at a concentration of $10 \mu \mathrm{m}$. Results obtained are the mean of at least three determination, carried out in triplicate (Table 1).

Ex vivo vasorelaxing activity: All the experimental procedures were carried out following the guidelines of the European Community Council Directive 86-609. The effects of the compounds were tested on isolated thoracic aortic rings of male normotensive Wistar rats $(250-350 \mathrm{~g})$. After a light ether anesthesia, rats were sacrificed by cervical dislocation and bleeding. The aortae were immediately excised, freed of extraneous tissues and the endothelial layer was removed by gently rubbing the intimal surface of the vessels with a hypodermic needle. Aortic rings ( $5 \mathrm{~mm}$ wide) were suspended, under a preload of $2 \mathrm{~g}$, in $20 \mathrm{~mL}$ organ baths, containing Tyrode solution (composition of saline in $\mathrm{mm}: \mathrm{NaCl} 136.8, \mathrm{KCl}$ 2.95, $\mathrm{CaCl}_{2} 1.80, \mathrm{MgSO}_{4} 1.05, \mathrm{NaH}_{2} \mathrm{PO}_{4} 0.41, \mathrm{NaHCO}_{3}$ 11.9, glucose 5.5), thermostated at $37{ }^{\circ} \mathrm{C}$ and continuously gassed with a mixture of $\mathrm{O}_{2}(95 \%)$ and $\mathrm{CO}_{2}(5 \%)$. Changes in tension were recorded by means of an isometric transducer (Grass FTO3), connected with a computerized system (Biopac). After an equilibration period of $60 \mathrm{~min}$, the endothelium removal was confirmed by the administration of acetylcholine ( $\mathrm{ACh} ; 10 \mu \mathrm{M})$ to $\mathrm{KCl}(30 \mathrm{~mm})$ pre-contracted vascular rings. A relaxation $<10 \%$ of the $\mathrm{KCl}$-induced contraction was considered representative of an acceptable lack of the endothelial layer, while the organs, showing a relaxation P10\% (i.e. significant presence of the endothelium), were discarded. From 30 to $40 \mathrm{~min}$ after the confirmation of the endothelium removal, the aortic preparations were contracted by a single concentration of $\mathrm{KCl}(30 \mathrm{~mm})$ and when the contraction reached a stable plateau, threefold increasing concentrations of the tested compounds $(1 \mathrm{nM}-10 \mu \mathrm{M})$ were added. Preliminary experiments showed that the $\mathrm{KCl}(30 \mathrm{~mm})$-induced contractions remained in a stable tonic state for at least $40 \mathrm{~min}$. The same experiments were carried out also in the presence of a well-known GC inhibitor: ODQ $1 \mu \mathrm{M}$ which was incubated in aortic preparations after the endothelium removal confirmation. The vasorelaxing efficacy was evaluated as maximal vasorelaxing response $\left(E_{\max }\right)$, expressed as a percentage of the contractile tone induced by $\mathrm{KCl} 30 \mathrm{~mm}$. When the limit concentration $10 \mu \mathrm{M}$ (the highest concentration that could be administered) of the tested compounds did not reach the maximal effect, the parameter of efficacy represented the vasorelaxing response, expressed as a percentage of the contractile tone induced by $\mathrm{KCl}$ $30 \mathrm{~mm}$, evoked by this limit concentration. The parameter of potency $\left(\mathrm{plC}_{50}\right)$ was calculated as negative logarithm of the molar concentration of the tested compounds evoking a half reduction of the contractile tone induced by $\mathrm{KCl} 30 \mathrm{~mm}$. The $\mathrm{plC}_{50}$ could not be calculated for those compounds showing an efficacy parameter lower than $50 \%$. The parameters of efficacy and potency were expressed as mean \pm standard error, for 6 experiments. Two-way ANOVA was selected as statistical analysis, $\mathrm{P}<0.05$ was considered representative of significant statistical differences. Experimental data were analyzed by a computer fitting procedure (software: GraphPad Prism 4.0).
In vivo studies: All animal manipulations were carried out according to the European Community guidelines for animal care (DL 116/92, application of the European Communities Council Directive of 24 November 1986 (86/609/EEC). The ethical policy of the University of Florence complies with the Guide for the Care and Use of Laboratory Animals of the US National Institutes of Health (NIH Publication No. 85-23, revised 1996; University of Florence assurance number: A5278-01). Formal approval to conduct the experiments described was obtained from the Animal Subjects Review Board of the University of Florence. Experiments involving animals have been reported according to ARRIVE guidelines. ${ }^{[39]}$ All efforts were made to minimize animal suffering and to reduce the number of animals used. Male Swiss albino mice $(23-25 \mathrm{~g}$ ) and SpragueDawley or Wistar rats (150-200 g) were used. The animals were fed with a standard laboratory diet and tap water ad libitum and kept at $23^{\circ} \mathrm{C}$ with a $12 \mathrm{~h}$ light/dark cycle, with light on at 7:00 AM. The analgesic activity of compounds was assessed by performing the abdominal constriction test, using mice into which a solution of acetic acid $\left(0.6 \%, 10 \mathrm{~mL} \mathrm{~kg}^{-1}\right)$ had been injected intraperitoneally (i.p.). The number of stretching movements was counted for 10 min, starting 5 min after administration.

New COX inhibitor preparation and docking: All calculations were performed using a blade (Intel-Xeon CPU) running Debian GNU/ Linux "Jessie" 8.1 64-bit operating system. Ligand's 3D conformations were generated from scratch. Marvin was used for drawing, displaying and characterizing chemical structures, Marvin 15.1.12.0, 2015, ChemAxon (www.chemaxon.com). OpenBabel was used to generate random conformation to run the cross-docking experiments by Vina COX-2. Docking procedure and detail were the same as previously reported. ${ }^{[31]}$

Keywords: CINODs · drug discovery · inflammation pharmacodynamics $\cdot$ COX-2 inhibitors

[1] P. Patrignani, C. Patrono, Biochim. Biophys. Acta 2015, 1851, 422-432.

[2] G. A. FitzGerald, C. Patrono, N. Engl. J. Med. 2001, 345, 433-442.

[3] Y. Cheng, S. C. Austin, B. Rocca, B. H. Koller, T. M. Coffman, T. Grosser, J. A. Lawson, G. A. FitzGerald, Science 2002, 296, 539-541.

[4] J.-M. Dogné, C. T. Supuran, D. Pratico, J. Med. Chem. 2005, 48, 2251 2257.

[5] R. S. Bresalier, R. S. Sandler, H. Quan, J. A. Bolognese, B. Oxenius, K. Horgan, C. Lines, R. Riddell, D. Morton, A. Lanas, M. A. Konstam, J. A. Baron, N. Engl. J. Med. 2005, 352, $1092-1102$.

[6] P. McGettigan, D. Henry, JAMA J. Am. Med. Assoc. 2006, 296, 1633-1644.

[7] B. H. McCarberg, B. Cryer, Am. J. Ther. 2015, 22, e167-178.

[8] S. Consalvi, M. Biava, G. Poce, Expert Opin. Ther. Pat. 2015, 25, $1357-$ 1371.

[9] S. H. Hwang, A. T. Wecksler, K. Wagner, B. D. Hammock, Curr. Med. Chem. 2013, 20, 1783-1799.

[10] G. Palermo, A. D. Favia, M. Convertino, M. De Vivo, ChemMedChem 2015, DOI: 10.1002/cmdc.201500507.

[11] A. Martelli, M. C. Breschi, V. Calderone, Curr. Pharm. Des. 2009, 15, 614636.

[12] J. L. Wallace, L. J. Ignarro, S. Fiorucci, Nat. Rev. Drug Discovery 2002, 1, $375-382$.

[13] R. M. Palmer, A. G. Ferrige, S. Moncada, Nature 1987, 327, 524-526.

[14] L. J. Ignarro, J. Physiol. Pharmacol. 2002, 53, 503-514.

[15] J. O. Lundberg, M. T. Gladwin, E. Weitzberg, Nat. Rev. Drug Discovery 2015, 14, 623-641.

[16] Y. Zhao, P. M. Vanhoutte, S. W. S. Leung, J. Pharmacol. Sci. 2015, 129, $83-94$.

[17] U. Förstermann, W. C. Sessa, Eur. Heart J. 2012, 33, 829-837.

[18] J. L. Wallace, Physiol. Rev. 2008, 88, 1547-1565.

[19] K. R. A. Abdellatif, A. Moawad, E. E. Knaus, Bioorg. Med. Chem. Lett. 2014, 24, 5015-5021. 
[20] A. Bhardwaj, Z. Huang, J. Kaur, E. E. Knaus, ChemMedChem 2012, 7, 62 67.

[21] M. A. Chowdhury, K. R. A. Abdellatif, Y. Dong, G. Yu, Z. Huang, M. Rahman, D. Das, C. A. Velázquez, M. R. Suresh, E. E. Knaus, Bioorg. Med. Chem. Lett. 2010, 20, 1324-1329.

[22] K. Chegaev, L. Lazzarato, P. Tosco, C. Cena, E. Marini, B. Rolando, P.-A. Carrupt, R. Fruttero, A. Gasco, J. Med. Chem. 2007, 50, 1449-1457.

[23] E. Del Grosso, D. Boschi, L. Lazzarato, C. Cena, A. Di Stilo, R. Fruttero, S. Moro, A. Gasco, Chem. Biodiversity 2005, 2, 886-900.

[24] M. Biava, G. C. Porretta, A. Cappelli, S. Vomero, F. Manetti, M. Botta, L. Sautebin, A. Rossi, F. Makovec, M. Anzini, J. Med. Chem. 2005, 48, 3428 3432.

[25] M. Biava, G. C. Porretta, G. Poce, S. Supino, S. Forli, M. Rovini, A. Cappelli, F. Manetti, M. Botta, L. Sautebin, A. Rossi, C. Pergola, C. Ghelardini, E. Vivoli, F. Makovec, P. Anzellotti, P. Patrignani, M. Anzini, J. Med. Chem. 2007, 50, 5403-5411.

[26] M. Biava, G. C. Porretta, G. Poce, S. Supino, F. Manetti, S. Forli, M. Botta L. Sautebin, A. Rossi, C. Pergola, C. Ghelardini, M. Norcini, F. Makovec, A Giordani, P. Anzellotti, R. Cirilli, R. Ferretti, B. Gallinella, F. La Torre, M Anzini, P. Patrignani, Bioorg. Med. Chem. 2008, 16, 8072-8081.

[27] M. Anzini, M. Rovini, A. Cappelli, S. Vomero, F. Manetti, M. Botta, L. Sautebin, A. Rossi, C. Pergola, C. Ghelardini, M. Norcini, A. Giordani, F. Makovec, P. Anzellotti, P. Patrignani, M. Biava, J. Med. Chem. 2008, 51, $4476-$ 4481.

[28] M. Biava, G. C. Porretta, G. Poce, C. Battilocchio, F. Manetti, M. Botta, S Forli, L. Sautebin, A. Rossi, C. Pergola, C. Ghelardini, N. Galeotti, F. Makovec, A. Giordani, P. Anzellotti, P. Patrignani, M. Anzini, J. Med. Chem. 2010, 53, 723-733.

[29] M. Biava, G. C. Porretta, G. Poce, C. Battilocchio, M. Botta, F. Manetti, M. Rovini, A. Cappelli, L. Sautebin, A. Rossi, C. Pergola, C. Ghelardini, N. Galeotti, F. Makovec, A. Giordani, P. Anzellotti, S. Tacconelli, P. Patrignani, M. Anzini, Curr. Med. Chem. 2011, 18, 1540-1554.

[30] C. Battilocchio, G. Poce, S. Alfonso, G. C. Porretta, S. Consalvi, L. Sautebin, S. Pace, A. Rossi, C. Ghelardini, L. Di Cesare Mannelli, S. Schenone, A. Giordani, L. Di Francesco, P. Patrignani, M. Biava, Bioorg. Med. Chem. 2013, 21, 3695-3701
[31] S. Consalvi, S. Alfonso, A. Di Capua, G. Poce, A. Pirolli, M. Sabatino, R. Ragno, M. Anzini, S. Sartini, C. La Motta, L. Di Cesare Mannelli, C. Ghelardini, M. Biava, Bioorg. Med. Chem. 2015, 23, 810-820.

[32] A. Di Capua, C. Sticozzi, S. Brogi, M. Brindisi, A. Cappelli, L. Sautebin, A. Rossi, S. Pace, C. Ghelardini, L. Di Cesare Mannelli, G. Valacchi, G. Giorgi, A. Giordani, G. Poce, M. Biava, M. Anzini, Eur. J. Med. Chem. 2016, 109, 99- 106.

[33] M. Biava, G. C. Porretta, G. Poce, C. Battilocchio, S. Alfonso, M. Rovini, S. Valenti, G. Giorgi, V. Calderone, A. Martelli, L. Testai, L. Sautebin, A. Rossi, G. Papa, C. Ghelardini, L. Di Cesare Mannelli, A. Giordani, P. Anzellotti, A. Bruno, P. Patrignani, M. Anzini, J. Med. Chem. 2011, 54, 7759-7771.

[34] M. Biava, C. Battilocchio, G. Poce, S. Alfonso, S. Consalvi, G. C. Porretta, S. Schenone, V. Calderone, A. Martelli, L. Testai, C. Ghelardini, L. Di Cesare Mannelli, L. Sautebin, A. Rossi, A. Giordani, P. Patrignani, M. Anzini, Eur. J. Med. Chem. 2012, 58, 287-298.

[35] M. Anzini, A. Di Capua, S. Valenti, S. Brogi, M. Rovini, G. Giuliani, A. Cappelli, S. Vomero, L. Chiasserini, A. Sega et al., J. Med. Chem. 2013, 56, $3191-3206$

[36] A. Martelli, L. Testai, M. Anzini, A. Cappelli, A. Di Capua, M. Biava, G. Poce, S. Consalvi, A. Giordani, G. Caselli, L. Rovati, C. Ghelardini, P. Patrignani, L. Sautebin, M. C. Breschi, V. Calderone, Pharmacol. Res. 2013, $78,1-9$.

[37] M. Biava, C. Battilocchio, G. Poce, S. Alfonso, S. Consalvi, A. Di Capua, V. Calderone, A. Martelli, L. Testai, L. Sautebin, A. Rossi, C. Ghelardini, L. Di Cesare Mannelli, A. Giordani, S. Persiani, M. Colovic, M. Dovizio, P. Patrignani, M. Anzini, Bioorg. Med. Chem. 2014, 22, 772-786.

[38] I. K. Khanna, Y. Yu, R. M. Huff, R. M. Weier, X. Xu, F. J. Koszyk, P. W. Collins, J. N. Cogburn, P. C. Isakson, C. M. Koboldt, J. L. Masferrer, W. E. Perkins, K. Seibert, A. W. Veenhuizen, J. Yuan, D.-C. Yang, Y. Y. Zhang, J. Med. Chem. 2000, 43, 3168-3185.

[39] C. Kilkenny, W. J. Browne, I. C. Cuthill, M. Emerson, D. G. Altman, J. Pharmacol. Pharmacother. 2010, 1, 94-99.

Received: February 8, 2016

Revised: April 8, 2016

Published online on May 27, 2016 